\title{
The Malian Crisis: Multiple Actors with Diverse Interests and Values
}

\author{
John Bosco Nizeimana (MSc. IR) \\ Dept. of Political and Administrative Studies, University of Zimbabwe \\ MP 167, Mt. Pleasant \\ Harare, Zimbabwe \\ Alfred G. Nhema (Ph D) (Corresponding author) \\ Dept. of Political and Administrative Studies, University of Zimbabwe \\ MP 167, Mt. Pleasant \\ Harare, Zimbabwe \\ Email: agnhema@gmail.com
}

Doi:10.5296/ jpag.v5i3.8273 URL: http://dx.doi.org/10.5296/ jpag.v5i3.8273

\begin{abstract}
The African continent has registered the highest number of civil wars compared to other regions of the world. Although lasting peace and security have eluded the African continent, the tenacity to right wrongs and skirmishes within the continent has been real but abortive. The exclusionary political systems in Africa have created an environment in which various groups contending for power are excluded from the political and economic processes through various repressive measures and the 2012 crisis is an event that testifies to this assertion. The involvement of France, regional and international organisations, state and non-state actors in the conflict attest to the fact that the Malian crisis was an event of multiple actors with diverse interests and values at stake. The paper observes that France's role in the conflict was mainly more humanitarian than interest driven. However, the year 2015 became a defining moment in the history of Mali as it steered in a new phenomenon of peace accord aimed at renouncing the long lived rivalry between the southern and northern based societies. The aim of this paper is to analyse and provide a comprehensive understanding of the 2012 Malian crisis and come up with the necessary prescriptions aimed at ensuring durable peace that will facilitate social economic growth in the war torn country. To substantiate the central objective of this paper, the paper relied mainly on documentary search.
\end{abstract}

Keywords: Exclusionary political systems, multiple actors, humanitarian and economic interests 


\section{Introduction}

The international arena has undergone a major transformation in the aftermath of the cold war. The post cold war witnessed a paradigm shift from interstate to intrastate conflict characterized by civil wars. In the history of international politics and conflicts, the nation of Mali has been known for its political turmoil ranging from coup de 'tats, civil unrests, external invasions and occupations. The crisis sparked off in 2012 and only ended in 2015 with the signing of a peace agreement between the warring factions. The peace agreement was reached through various multi-faceted negotiation attempts by national, regional and international payers. The role of the former colonial power France is highlighted as having contributed to a large extent in ending the war in Mali.

The French intervention has received mixed reviews with some condemning the country for for its perceived double standards that seek to promote its interests in the Malian conflict whilst simultaneously pursuing a humanitarian stance. The conflict drew both regional and international actors. This resulted in the signing of the Peace Accord in 2015. The paper seeks to examine and highlight the nature, scope and interests of multiple actors in the conflict. This paper also attempts to provide plausible recommendations to the conflict that include the need to embrace inclusionary political and economic measures.

\section{The crisis in Mali 2012: An overview}

The nation of Mali is a landlocked state surrounded by seven neighbouring countries that include Niger, Burkina Faso, Algeria, Mauritania, Senegal, Ivory Coast, and Guinea. Geographically, the country is large with a population of 15,8 million. The conflicts in Mali started in March 2012 when the Northern based Tuareg rebel group attacked cities in Northern Mail, following the instability engineered by a military coup led by Major Kamara and his loyalists in the country. The rebel military group attacked the key towns in the Northern part of Mali and proceeded to occupy some key territories.

Northern Mali has a very low population density with just 1, 3 million inhabitants out of 14.5 million in Mali as a whole. Among the community living in the North include the Tuareg, Arabs and the Fulan that are deeply divided along ethnic and cultural lines. (Moss, 2012). The majority of the Malian in that region belong to the Sufi tradition of Islam that accommodates secularism and venerates saints, in contrast to the puritanical Sunni tradition based on its orthodox interpretation of Islam (Ibid, 2012). This demonstrates the extent to which this community is heavily divided: it is a complex society with several belief system, norms and values.

The conflict in Mali originated from the long standing skirmishes and the perceived injustices faced by the Northern based society. Also, it is should be noted that low intensity conflict was already present over the years through the various clashes between the nomadic traditional Tuareg community's way of life and that of the communities of the South. Many people living in the North view their region as being an area that is subjected to exploitation and marginalization. As noted by Nhema, in Africa, one of the major sources of conflict in countries facing political instability challenges is the prevalence of exclusionary political 
systems that have created an environment in which various groups contending for power are excluded from the political and economic processes through various repressive measures thereby creating instability in the continent (Nhema, 2004, Nhema and Zeleza, 2008).

People from the North claim to have been marginalised since independence and before. This grievance dates back to French colonial rule that excluded them from the centres of power during the colonial era. Historically, the Tuareg are nomadic people who have lived in the Sahel and the Sahara region of Mali, Nigel and Algeria. Up to the time of the clashes in 2012, the Tuareg were not well represented at the central government institutional levels and the economic activities arenas.

The marginalisation and exclusion of the minority Tuareg and failure of post colonial governments to address the Tuareg grievances from a holistic perspective became one of the major sources of conflict for the rebel movement in the North. This issue of marginalisation is considered by many analysts as one of the forces that motivated the Tuareg to engage in military conflict with the Malian government.

According to Diallo (2012:33) the instability and rebellions are perennial features of Malian political life. Other factors that accelerated the crisis in Mali were the periods of drought and extreme poverty that existed in the country. This intensified the situation, in which the political scene within the country was overshadowed by the struggles for power, taking the shape of successive coups and dictatorships (Ibid, 2012). Added to that is the fact that Mali has been ranked among the poorest nations across the globe. Since the achievement of independence from the French, Mali has been known for its geographical mapping line, which divides the country into two slices: the 'North and South'. Bamako, the capital city is located in the South while the Northern side hosts the cities of Gao, Kidal and Timbuktu. These northern based cities were the most affected by the presence of drought and famine. Food insecurity became the song of the day in this region. This led to weak economic status dominated by social disruptions. Thus, the crisis erupted when the nation was faced by an already uncertain future.

In addition, other factors which further worsened the conflict are that the Sahel region is regarded as one of the most difficult places on earth for any human being to survive. Accordingly, Mali is the world $24^{\text {th }}$ largest country with its northern region deep in the Saharan boarders. For the past decades, many countries in the Sahel region suffer from conflicts and most of them fit into the categorization of fragile states. Whenever there are challenges affecting one country in the region, they end up having a contagion spill-over effect in the neighbouring states. An example that can be cited is the case of the drought in Niger in 2012. The 2012 food crisis in Niger was compounded by instability in neighbouring Mali as thousands of refugees fled the conflict in Mali (Human Development Report 2014).

There are scholars such as Ibrahim (2013) who believe that the 2012 conflict in Mali was caused by decades of poor governance after the 1968 military coup that the country experienced. Not only that, this unstable scenario was followed by a fragile democratic transition in 1992. The country was therefore characterised by weak state institutions and nepotism, corruption and an insensitive ruling elite (Ibid 2013). The country is ranked $105^{\text {th }}$ 
out of 182 countries profiled in Transparency International of 2012 corruption perception index (Transparency International Report 2012). It is quite clear from the preceding discussion that the conflict in Mali was facilitated by many complex related factors reviewed above. All these factors combined with other grievances ignited the 2012 Malian conflicts breakout.

\section{Theoretical considerations}

For the purpose of coming up with a comprehensive understanding of the Malian crisis, the theory of greed and grievance is a contributory tool that is useful to acknowledge in this paper. The Malian conflict can be explained within the framework of the greed versus grievance theory as propounded by Collier and Hoeffler (2004). The chief proponents of this theory were trying to unravel the causes of conflicts and explain the reasons why some conflicts exist in certain settings more than others. The greed and grievance theory is trendy in political science discourse and has been used as an analytical tool for understanding conflicts, particularly on the African continent. The greed and grievance theory postulates that the countries with abundant resources, natural resources in particular, are more prone to violent conflicts than those without (Ibid, 2004). The advocates of this theory are of the view that insurgents groups are more likely motivated by control over resources than by actual political differences and ethnic division considerations (Ganesan and Vines 2004). There is however a growing recognition of the analytical limits that the theory imposes on what in reality are highly complex systems of social interactions (Ballentine and Nitzschke 2003). In other words, this theory is useful but cannot obviously be used to explain all conflict scenarios. The model, cannot, however be ignored when analysing the nature of conflicts but rather should be utilised with caution given the divergent nature and form of factors that characterise some conflicts.

Historically, the Tuareg are people who lived in the Sahel and Saharan region of Mali, Nigel and Algeria. With regard to the tenets of the greed and grievance theory highlighted above, their fundamental grievance is their claim of experiencing decades of marginalisation, discrimination and exclusion from the political and economic processes by the successive Bamako based governments. The discrimination and the exclusion remained the major uniting force that led the Tuareg to take arms fighting for a separatist state and the rights of the Tuareg minorities in Northern Mali. Poverty, poor governance, marginalisation, the exclusion of a large section of the Malian populace from the political and the economic process and the failure to address fundamental grievances by the ruling class in Mali created a breeding ground for the Tuareg people to gain a foothold and organise themselves, (Francis 2013). Therefore, given the above, the greed and grievance theory is a relevant tool in explaining the root causes of the Malian crisis and in highlighting the nature of forces behind the taking up of arms by the Tuareg people.

As noted earlier, people in the northern parts of Mali view themselves as being oppressed and exploited. The end of Malian great empires and the French colonisation proceeded with the exclusion of the northern region from the centres of power. The exclusionary policies that led to the marginalisation of people in the North after independence in 1963 led to the growth of 
grievances within the mind-sets of societies in that region against the Malian government (Ibrahim 2013). Since the independence of Mali in 1963, the Tuareg and the Arab populations in the North have never been fully incorporated into the political and economic spheres by successive Malian governments. They have been regularly marginalised from the positions of power and development projects (Ibid 2013). The political and economic marginalisation of the northern region can be adequately explained through the use of the greed and grievance theory, as being among the root causes of the 2012 Malian crisis.

\section{The French intervention in Mali: Balancing Interest and Humanitarian Values}

Humanitarian intervention efforts have been subjected to spirited debates across the globe. The NATO intervention in Kosovo in 1999, the 2011 NATO intervention in Libya, the 2003 US involvement in Iraq to mention just but a few, are among the events that arouse major questions on whether the aims were humanitarian in nature or country interest based.

While one cannot deny that the factors behind the French intervention in Mali were partly based on country interests, there is a widely held view that the initiative was also driven by humanitarian elements. For example, the claim that there was a need to protect and prevent what was being viewed as an imminent massacre of civilians on both sides of the conflict is well accepted. Among these factors were the imminent attack on and possible capture of Bamako and the potential instability consequences for Mali, its neighbours and the volatile region. However, French national interests in the region are well known given the colonial ties between the two countries. In this conundrum, the French had to balance their interests and humanitarian values. With that background, the paper will now analyse the factors behind the French intervention during the 2012 Malian crisis.

It is important to note that the French military intervention in Mali did not come as a surprise to many scholars as the country was one of the international actors most deeply involved in the Malian crisis since the outbreak in 2012. As noted by Hussey (2013:10), France has been the major player responsible for internationalizing the discussion on the Malian crisis, and behind the issuing of three UN Security Council Resolutions, under Chapter Seven of the UN Charter. French political pressure was also the decisive factor that drove ECOWAS to send its forces to Mali, with the aim of preserving the state's territorial integrity. The French therefore played an instrumental role in internationalising the Malian crisis. In the process, the international community became aware of what was taking place in Mali. This was very crucial for the French, the Malian people and Africa. Therefore, the main important contribution of the French intervention in the Malian conflict was primarily to bring the crisis to an international level, thereby mobilizing regional and international support for the government in Bamako. It is however also important to acknowledge the role played by other African countries in supporting the French in their operations. For example, the French relied on the military efforts of the Economic Community of West African States (ECOWAS) member states that provided their forces with logistical, financial and advisory support (Hussey, 2013).

Significantly, the French can be attributed to have achieved the immediate and short term goals and objectives of their intervention which included preventing the takeover of Bamako 
by the Northern based rebels. Among the other objectives of France in the Malian crisis was the need to help the government re-establish its control and sovereignty over its jurisdictional territory (Francis 2013). This putative short term success of the French intervention led to calls for the deployment of African troops and the UN peace keeping forces to replace the French forces in Mali. It is apparent that France played an important role in the prevention of a humanitarian crisis on the African soil. If the French had not taken this decisive role during the Malian crisis, the African continent could have witnessed another genocide on its soil.

The French military intervention was therefore quite significant as it brought about a swift and decisive military end to the civil strife and conflict in northern Mali. In their attempt to justify their role in Mali, President Hollande of France argued that his country had no alternative but to intervene and prevent the emergence of a terrorist state that would have posed serious security repercussions for France and the western world (Francis, 2013). Expectedly, the issue of the counter-terrorism campaign is of critical French national interest in the West African region. France had predicted the presence of terror groups in Mali and had to act swiftly to prevent them from spreading their influence. At the same time, France also feared that Mali could become a retreat and training haven for any terrorist groups if the state of Mali were to be occupied by the Northern Malian rebels. Given the above perceived threats, France felt that it was justified in its involvement in Mali on the grounds of fighting terrorism. The jury is out on the issue of whether this was a humanitarian pretext or an interest based justification and this explains why there is always a dilemma when trying to balance both country interests and humanitarian concerns simultaneously.

Other analysts argue that the real motive for French intervention in Mali is to protect French economic interests in the country and in the neighbouring country of Niger (Elischer 2013). The spill over of the conflict into Niger and the potential implosion of that country would have devastating impacts on French economic interest in the region. It is believed that France has mining interests in the region. Thus, it was necessary to protect them. Imperatively, it is vital to note the fact that France depends heavily on uranium imports from Niger for its energy security since the nuclear power is an important primary source of electricity. Therefore the security and stability of Niger is a vital national security interest for France.

Among the other forces that explain the presence of the French is the need to protect their sources of raw materials from other great power nations. In other words, the intervention is an attempt to maintain colonial ties between the two nations but in a diplomatic manner. The French intervention was therefore motivated by the rising levels of competition from China and Russia in the region. Like its other alliance partners, France had similar intentions of securing its interests. For instance, some scholarly analysts note that France wanted to secure the energy resources of the Sahel and deter rival powers such as China, Russia, and India and to a lesser extent Brazil, (Roland 2012). In this case, the main threat to the French is the Chinese foreign policy on the African continent as China has already received the permission to exploit oil in Niger. This therefore partly explains the French intervention in Mali during the crisis.

The presence of France in Mali 2012 ushered in a new dimension to the understanding of the 
French involvement in the West African region. As noted by Ibrahim (2013:21) not only does France have economic interests in the Sahel region, it has traditional and historical influence in the region. Therefore given the above viewpoint, France's intervention in Mali was an attempt to re-draw its influence against the increasing Chinese dominance on the African continent. In brief, the Malian crisis presented an opportunity for the French to pursue and cement their foreign policy influence in the region and on the African continent.

Several questions have been brought forward concerning the role of the French in the Malian crisis. Whether the French presence in the West African nation was a humanitarian or interest oriented is a subject of debate. As noted, the French faced a standing dilemma of balancing interest and humanitarian values. However, despite the aforementioned arguments, the French intervention succeeded in achieving the intended objective of ending the advance of the Tuareg group from occupying the southern parts of Mali including the capital city of Bamako. France also played an important role in preventing the mass killing of civilians on both sides, despite the fact that their intervention had other objectives of promoting their national interests the region.

However, despite the French efforts in preventing mass killings of civilians in Mali, it will be pointless not mention the gaps and ambiguities left by their involvement in the conflict. One of the weaknesses exposed by the French in the region and Africa at large is lack of unity (Francis 2013). Cognisant of the above, Africa as a continent under the African Union lacked a guiding united position on the Malian crisis. Dealing with a threat collectively on the continent remains an aspiration, as the Malian crisis once again exposed the extent to which African states and regional organisations cannot deal with a continental threat in a proactive manner. Ideological differences have largely hampered the regional states and their leaders. The question that remains unanswered is how effective, real and viable is the philosophy of 'African solutions to African problems' in Africa.

\section{The Role of Multi-Track diplomacy in resolving the Malian Crisis}

The complexity of interstate and intrastate conflict has become a critical challenge to the field peace and security across the globe and to the methods of conflict resolution as well (Nhema, 2004; Nhema and Zeleza, 2008). Even though the number of conflicts have decreased since 1999, with the year 2005 having the lowest number since the end of the cold world (SIPPRI Yearbook, 2006), the prevalence of ethnic conflicts has proven that ideological differences are no longer the major cause of conflicts. Ethnic identity and the distribution of the resources are today a major cause of violence (Lederach, 1995:23). In trying to find the best methods of resolving conflicts, a variety of diplomacy typologies have been identified. The effort to resolve these conflicts has been a big task to the relevant authorities involved in conflict resolutions.

The contemporary conflicts management strategies have for many years been dominated by negotiation and persuasions. Thus, increasingly, terms such as Track One diplomacy and Multi-track diplomacy are common in conflict resolutions lexicon (Montiville, 1996). The track one diplomacy is defined as an official state centric way of conflict resolution through the use of state actors. Track One diplomacy differs from the Multi-track diplomacy which 
is defined as an unofficial way of conflict resolution through official and unofficial actors. In the case of Mali, the multi-track diplomacy was put to test when trying to resolve the 2012 crisis. Accordingly, the actors who were involved in the Malian crisis comprised of players such as the French, the African Union, Norway, NGOs, the United Nations, Churches, Civil society organisations and individual actors as shall be seen below. In the ensuing section, the paper will now analyse the role of multi-track diplomacy in the Malian crisis.

The crisis in Mali led to various initiatives ranging from national, regional and international military engagements aimed at resolving the conflict. However, the most acknowledged effort is that of the French that was important in bringing about a quick end to the conflict in northern Mali. France also assisted in the signing of the 2015 peace accord to end the conflict. France was therefore one among other important key players that has been deeply involved in resolving the Malian crisis from a multi-track diplomacy perspective.

The resolution of the Malian crisis was met through the efforts of various actors as argued earlier on. The UN resolution 2088 on Mali provided a platform for the involvement of these players that included ECOWAS member states. (Ibrahim, 2013). Other essential players in the conflict other than France and the UN were the European Union (EU). These organisations played a significant role of facilitating the mediation processes under conflict resolution and transformation mechanisms. The UN and EU provided military trainers to rebuild the Malian army and the training of African forces for deployment in Mali, (Ibid 2013). The EU also mobilised international funding support of the UN backed African-led International Support Mission to Mali (AFISMA) deployment. At the same time, the EU facilitated the Brussels meeting focused on humanitarian aid support, post war peace building and state reconstruction involving the World Bank and the Monetary Fund. This shows the extent to which multi-track diplomacy was used in resolving the Malian crisis.

The role of other non state actors in the conflict cannot be underestimated. According to Cunningham (2013) local organizations played an instrumental role on humanitarian settings. They were involved in supporting the vulnerable people, refugees, widows, orphans and the aged people who were struggling in the conflict. For example, the NGO Christian Aid and its sister organization Norwegian Church Aid are among the major players who were deeply involved in the conflict. These organizations, were in most cases able to penetrate the most conflict prone areas and assist the victims with some basic requirements provisions. For instance, the Menaka based people were given food despite the fact that the region was under the rebellion occupation. However this was mainly facilitated by the Groupement artisans Ruraux d'Intadeyneé (GARI), a local organization based in the Northern parts of Mali. This organization is heavily accredited for its good relations with the local communities and its ability to use informal channels to deliver humanitarian aid to people in need (Cunningham, 2013). This therefore shows the extent to which the conflict of Mali was approached from various angles, and this further reveals an important aspect of multi-track diplomacy in this particular conflict.

The multi-track diplomacy in Mali has however faced some challenges. Due to multiple actors in the conflict, the process of conflict resolution has been hampered by poor 
coordination. For example, both the UN and the EU like ECOWAS and the AU have been criticised for inaction in Mali. This is because they failed to have proper coordinated channels of communication. Some countries wanted to promote their national interest and others had strategic interests at stake, hence this made it difficult for the multi-track diplomacy to yield the needed positive results. Also these actors failed to appreciate the extent to which the state of Mali was fragile and the inability of the national army to lead the military offensive against the combined rebels in the north (Ibid 2013). The UN also did not initially grasp the threat posed by the Malian crisis to international peace and security. It also under estimated the military strength and capability of the well trained and well equipped rebels from the North (Plette 2013).

The above examples are just meant to highlight a few of the challenges that the multi-track diplomacy model faced at the practical levels in resolving the Malian conflict. Be that as it may, it can be safely contended that if it was not for the Multi-track diplomacy, the 2015 peace accord signed to end the war would not have been achieved. The involvement of multiple actors led to the internationalisation of the conflict. In contemporary conflict management, whenever a conflict is brought to the international stage, it becomes easier for the multi-track diplomacy framework to work. In this case, the multi-track diplomacy was an instrumental mechanism utilized in resolving the Malian crisis.

\section{The 2015 Peace Accord: A brief analysis}

The 2015 peace accord is a defining moment in the history of the nation of Mali. The county endured several clashes between the Northern and Southern regions of Mali in which civilians, woman and children were the victims. The 2015 peace accord came as a salvation to both parties to the conflict. Most of the stakeholders to the conflict were ready to end the conflict. A way out of this crisis became necessary for all Malians and the international community at large. Finally, the Bamako based government and the Tuareg -led rebel groups signed a land mark peace deal to end the years of fighting in the country. Mention must be made of the role of the Algerian government whose efforts towards ending this long conflict through dialogue was an important factor. The Algerian brokered deal was signed by a representative of the rebel movement of the National Movement for the Liberation of Azawad (MNLA) in the Malian capital Bamako in a bid to end the cycle of conflict in the country (Pezard and Shurkin, 2015).

The dominant objective of this peace accord is to bring stability to the country's vast Northern desert. The northern region has been for many years subjected to underpinnings of several Tuaregs uprising since 1960s. As noted by Pezard and Shurkin the warring parties to the conflict finally agreed to commit themselves to a peace pact on 5 June 2015 (Ibid, 2015). The Tuareg rebels led movement only agreed after being assured that its fighters would be included in the regular security forces of the country, and that the residents of the Northern region would be fairly represented in government institutions, among other concessions, (Ibid 2015). This peace accord has been regarded as one of the first steps towards achieving a durable peace solution in Mali. It is now the obligation of the implementers to adhere themselves to the agreed term and conditions of the peace accord. 
As noted by Reeves (2015), the important terms of the 2015 peace accord in Mali included a commitment to a unified, secular Malian state rather than an asymmetric federation with autonomy for the Northern region. The viability of this agreement will depend on the political will of the leadership. In other words, the peace accord gave the Northern region some discretion on the use of financial resources and limited political autonomy arrangements to directly elected regional assemblies in the North. This will strengthen ties between the North and the South, provided there is a strong mutual trust base. Other topical issues of the 2015 peace accord encapsulate Disarmament, Demobilisation, Reintegration and Reinsertion (DDRR) of the Northern armed groups including the merging of undefined numbers of fighters into the national security force. Likewise, success of disarmament is hinged on mutual trust mainly because disarmament produces high levels of mistrust. There is need for mutual trust to spearhead the implementation of the signed peace accord.

The need to promote sound and viable developments projects in the Northern Mali was another indispensable dimension emphasised in the peace accord framework. The 2015 peace accord that was mediated by Algeria seeks to promote investment in the northern economic growth and development with the purpose of ending disparities in the region, (Reeves, 2015). The framework calls for more investment flows to the Northern based communities. However, the success of this determination depends on the levels of accountability and transparency present in public institutions as well as private. Significantly, the 2015 peace accord is aimed at achieving a greater inclusion of the Northern population in national institutions. To do this, the peace framework includes more elected seats in the National Assembly for traditional leaders in the new senate and guarantees representation in government institutions (Ibid, 2015). For this to be effective, there is need for the government to have strong institutions that are corruption free. Reform processes must be carefully done to ensure that the deep-rooted peace agreement arrived at is not compromised in the country.

Despite the 2015 Peace Accord being signed by the warring parties to the conflict in Mali, some scholars such as Reeves (2015) still hold some reservation over the success of this peace accord. He argues that, in spite of seven months of negotiations the 'devil' remains in the detail of the Algiers Accord. The future prospect of this peace accord is uncertain and will depend on how the various peace provisions enshrined in the agreement are implemented. The crux of the agreement is the devolution of power to the regional assembly rather than a single legislative entity for the entire north or the national state of the Azawad (Ibid 2015). The paper's argument is that the success of this peace accord among the Malians is not guaranteed as it depends on the political will of those in leadership positions. Implementation processes must also be backed by strong institutions and mutual trust that can act as catalysts that drive every process aimed at bringing peace and social development in Mali.

As highlighted in various sections of this paper, the Malian crisis started in March 2012 when the Tuareg rebel group attacked towns in Northern Mali. This led to major displacements of the population in the affected areas. The crisis engineered by the rebels in the North attracted international attention from different angles. To understand the nature of the Malian crisis that 
broke out in 2012, the paper utilised the greed and grievance theory to help explain the nature and form of the conflict in Mali. The marginalisation and political exclusion of the Northern populace is one important factor depicted by this paper that led to the Tuareg uprising against the Malian government based in Bamako. After the outbreak of this crisis, the international focus led by France was important as it led to concerted efforts that eventually led to the participation of both internal and external state and non state actors in resolving the conflict.

The French intervention has been widely acclaimed for its intentions of restoring the integrity and sovereignty of the Malian government. The intervention has also been criticised for being interest driven. Other international and regional organisations such as the UN, ECOWAS and the AU are among the major actors that played an important role in the Malian crisis. These organisations were instrumental in promoting dialogue within the warring parties to the conflict. Also, the vital role played by the Algerian government as well as the neighbouring states in mediating the negations that led to the peace accord must be appreciated.

The paper supports the view that calls for a fair distribution of resources should be adhered to. Such a system would assist in addressing the concerns of the Northern based groups of being excluded from the economic and political processes in the country. For long term peace and stability to be achieved, there is a need to focus on implementing inclusionary measures at the economic, institutional and social levels. This would address the Northern region's concerns of marginalisation, political exclusion and lack of access to fair distribution arrangements of resource sharing between the North and the South.

There is also a need to reform the existing institutions in order to make them more representative of the Malian society. This is important because it helps to create an accommodative environment for all Malians. People in the county must have confidence in their government and security systems and for this to be achieved there must be credible peace building initiatives and security sector reform processes within the country.

Since national elections are one of the major political events that determine the future of any country, there is need for electoral reforms and amendments with a view include the Northern populace in the electoral systems. This will make the citizens in the North feel more recognised and appreciated. Such psychological motivations will push them to work for the development of their country. As an attempt to achieve inclusiveness in the governance processes, the paper also recommends that the Malian government extends to traditional leaders a legal role as in the case of Niger and Burkina-Faso where some consultative prerogatives on specific and contentious issue are done through these traditional channels. They will be able to regulate tensions between communities and also assist streamline the relationships and rapport between the local populace and the central government (Lacher 2013). This is vital as it is a way of appreciating the roles of traditional leaders as custodians of traditional culture, beliefs, norms and values in the running of their communities especially in Africa where tradition is highly emphasised and respected in various communities. 


\section{References}

Avezov, X and Timo, S. (2014). The Consensus Mali and International Conflict Management in a Multi Polar World. SIPRI Policy Brief. http://books.sipri.org/files/misc/SIPRIPB1403.pdf (Accessed on 31st August 2015)

Ballentine, K, \& Nitzschke, H. (2003). Beyong Greed and Grievance: Policy Lessons from Studies in the Political Economy of Armed Conflicts. International Peace Academy Policy (IPA),Report.http://www.worldpolicy.org/sites/default/files/imported/projects/arms/study/bak 05_1.pdf. Accessed on $31^{\text {st }}$ August 2015

Barbara, P. (2013). UN 'plans to fight rebels in DRC', http://www.bbc.com/news/world-africa-21208401 (Accessed on 31st 2015)

Boas, M. and Torheim, L.E. (2013). The Trouble in Mali-Corruption, Collusion, Resistance, Third World Quarterly, 34(7): pp. 1279-1292.

Cathy, H. (2013). France in Mali. What risk for the new Hollande?. London: Royal United Services Institute

Collier, P. and Hoeffler, K. (2004). Greed and grievance in civil war, Oxford University Press: Oxford Economic Papers, 56, 563 - 595

Cunningham, T. (2013). Mali: The vital Role of Local Civil Society. http://www.huffingtonpost.co.uk/tony-cunningham/mali-civil-society2899593.html.Accessed on $27^{\text {th }}$ August 2015

Elischer, S. (2013). After Mali comes Niger: West Africa's problems migrate east. February 12th. http:// www.foreignaffairs.com/files/images/Elischer AfterMali 411.pngFrench. Accessed on 15 August 2015.

Diallo, F. (2012). The War in Mali \& it Consequences for the Sub-region http://thinksecurityafrica.org/research/the-war-in-mali/. Accessed on $28^{\text {th }}$ August 2015

Francis, D, (2013). The Regional Impacts of the armed conflict and the French intervention in Mali, Oslo: Norwegian Peace Building Resource Centre (NOREF)

Ganesan, A. \& Vines, A. (2004). Engine of War: Resources, Greed and the Predatory State. Human Rights Watch. http://www.hrw.org/legacy/wr2k4/14.htm

Grégory, C. \& Thibault, V. (2012). The roots of Mali's conflict: Moving beyond the 2012 crisis, The Hague: Netherlands Institute of International Relations (Clingendael).

Hussey, A. (2013). Algiers: A city where France is the Promised Land - and still the Enemy, http://www.theguardian.com/world/2013/jan/27/algeria-france-colonial-past-islam

Ibrahim, J. (2013). Civil Society perspective on the Malian Crisis. www.premiumtimesng.com/.../120732-civil-society-perspective-on-themalian-crisis-1-by-jibrin-ibrahim.html (Accessed on $31^{\text {st }}$ August 2015).

Jean-Yves Le Drian, France's defence Minister, quoted in the Center for Geopolitical 
Analyses. Mali conflict: French troops 'dismantle al-Qaeda base. http://icmu.nyc.gr/Mali-conflict-French-troops-dismantle-al-Qaeda-base?page=1 (Accessed on 23 August 2015)

Keaten, J. (2012). France to send drones to Mali region, Associated Press, 22 October 2012, www.news.yahoo.com.

Lacher, W. (2013). The Malian crisis and the challenge of regional security cooperation. Stability: International Journal of Security \& Development, 2(2): 18, pp. 1-5,

Lederach, J.P. (1995). Preparing for Peace: Conflict Transformation Across Cultures. New York: Syracuse University Press.

Montiville, J.V. (1996). Foreword in Michael Henderson .1996. Forgiveness Factor: Stories of Hope in a World of Conflict. London, Grosvenor Books,xii-xviii.

Moss, T. (2012). Why Mali's Path to Peace Must Start in the South, Center For Global Development.

http://www.cgdev.org/blog/why-mali\%E2\%80\%99s-path-peace-must-start-south (Accessed on $28^{\text {th }}$ August 2015).

Nhema, A., G. and Zeleza, P.T (eds.). (2008). The Resolution of African Conflicts: the Management of Conflict Resolution and Post-Conflict Reconstruction. James Currey, Oxford and Ohio University Press, Athens. (224 pp).

Nhema, A.,G. and Zeleza, P.T (eds.). (2008). The Roots of African Conflicts: the Causes and Costs. James Currey, Oxford and Ohio University Press, Athens (288 pp).

Nhema, Alfred G. (ed.) (2004). The quest for peace in Africa: Transformation, democracy and public policy. Utrecht: The Netherlands, International Books (416 pp).

Pantucci, R. (2013). France Confronts Terror Threats in Africa, Risks Attack at Home. London: Royal United Services Institute.

Perry, A. (2013). The crisis in Mali: Will French air strikes stop the Islamist advance? Time Magazine $11^{\text {th }}$ January 2013, www.world.time.com. Accessed on 20 July 2015.

Pezard, S. \& Shurkin, M. (2015). Achieving Peace in Northern Mali: Past Agreements, local conflicts and the Prospects for a Durable Settlement. Santa Monica, Calif.: Rand Corporation.

Richard Reeve (2015), Five strategic failures of the French intervention in Mali http://thebrokeronline.eu/Blogs/Sahel-Watch-a-living-analysis-of-the-conflict-in-Mali/Five-st rategic-failures-of-the-French-intervention-in-Mali (Accessed on $28^{\text {th }}$ August 2015).

Roland, M. (2012). The camp in Mali: The result of a long term crisis or spill over from the Libyan war. Oslo: Norwegian Peace Building Resource Centre (NOREF)

Shulz, D. (2003). Political Factions, Ideological Fictions: the controversy over Family law reform in democratic Mali, Islamic Law and Society, 10(1), 132-164. 


\section{Macrothink}

Journal of Public Administration and Governance ISSN 2161-7104 2015, Vol. 5, No. 3

Transparency International. (2104). Corporate secrecy, global money laundering makes it harder for emerging economies to fight corruption. http://www.transparency.org/cpi2014/press

UNDP. 2104. Human Development Report. Sustaining Human Progress: Reducing Vulnerabilities and Building resilience. http://hdr.undp.org/en/2014-report

United Nations. 2012. United Nations Security Council 2012b, resolution 2085.SC/10870/. New York: United Nations Publications 